\title{
Relation of antivimentin antibodies to anticardiolipin antibodies in systemic lupus erythematosus
}

\author{
MARTIN A BLASCHEK, ${ }^{1}$ MICHAEL BOEHME, ${ }^{+}$JEAN JOUQUAN. 2 \\ ANNE-MARIE SIMITZIS, ${ }^{3}$ SPYROS FIFAS, ${ }^{5}$ AUL LE GOFF,? \\ AND PIERRE YOUINOU
}

From the Departments of ${ }^{1}$ Immunology, ${ }^{2}$ Rheumatology, and ${ }^{3}$ Microbiology, Brest University Medicat School, Brest, France; the ${ }^{4}$ Abteilung für Innere Medizin, Universitätsklinik, Ulm, West Germany; and the ${ }^{5}$ French National Institute of Marine Biology, Brest, France

SUMmary Tests for antivimentin antibodies (AVA) were performed on 50 systemic lupus erythematosus (SLE) and 63 control sera by indirect immunofluorescence and enzyme linke immunosorbent assay (ELISA). The prevalence was significantly raised in SLE ( $38 \%$ and $50 \%$ o $€$ sera positive for IgM-AVA and IgG-AVA, respectively, by immunofluorescence; $36 \%$ and $64 \%$ of sera positive for IgM-AVA and IgG-AVA, respectively, by ELISA) in comparison with the्ष control sera. A significant correlation existed between IgM-AVA, on the one hand, an anticardiolipin antibodies (ACA) and anti-single-stranded DNA (ssDNA), on the other. B stepwise principal component analysis demonstrated that IgM-AVA and IgG-AVA accounte for $71 \%$ of the total variance in SLE ( 50 patients $\times 5$ parameters=total variance). Twenty AGA positive serum samples from patients with syphilis were therefore tested for the presence AVA, but hardly any were found to be positive. IgM-AVA from patients with SLE werte inhibited by cardiolipin and absorbed with ssDNA. An association between AVA positivity $\overline{\mathrm{an}} \mathrm{\Phi}$ arthralgia was also shown in SLE.

Key words: anti-single-stranded DNA antibody.

Intermediate sized filaments are polymeric fibrous structures. ${ }^{1}$ Together with microfilaments and microtubules they form part of the extensive cytoplasmic network called the cytoskeleton. The collective term intermediate sized filaments refers to those filaments whose diameter is approximately $10 \mathrm{~nm}$, and therefore intermediate between that of microfilaments $(7 \mathrm{~nm})$ and microtubules $(25 \mathrm{~nm})$. Most cells contain only one type of intermediate sized filament. For example, epithelial cells contain keratin, whereas cells of mesenchymal origin, e.g., fibroblasts, contain only vimentin.

Vimentin has been shown to be a target for an autoimmune reaction, not only in bacterial, ${ }^{2}$ parasitic, ${ }^{3}$ and viral $^{4}$ infections, but also in rheumatic diseases, ${ }^{5-8}$ especially systemic lupus erythematosus (SLE).

Accepted for publication 19 February 1988.

Correspondence to Professor Pierre Youinou, Department of Immunology, Brest University Medical School, BP 824, F 29285. Brest Cedex, France
As part of our studies on anticytoskeletat antibodies ${ }^{9} 110$ we looked for the presence of ant? vimentin antibodies (AVA) in SLE sera, using a indirect immunofluorescence technique and a $\overline{\bar{\AA}}$ enzyme linked immunosorbent assay (ELISA). The second objective of the present work was to elicti information concerning the cross reacting specific ties and the interrelationship between AVA, on the one hand, and anticardiolipin antibodies (ACAP anti-double-stranded (ds) and anti-single-stranded (ss) DNA antibodies, on the other.

\section{Patients and methods}

PATIENTS

Fifty serum samples from patients with SLE were obtained from the Brest University Hospital. The group included eight men and 42 women, ranging i age from 10 to 71 years (mean 40.8), and meeting the Amerian Rheumatism Association preliminary and revised ${ }^{12}$ criteria for SLE. Patients wero selected because they were new patients at their firs 
encounter with us in the hospital (department of rheumatology and internal medicine). The serum was drawn at the same time that the clinical evaluation was performed. Stored sera from 20 patients with syphilis, as demonstrated by strongly positive Venereal Disease Research Laboratory slide flocculation and Treponema pallidum immobilisation tests, were also examined. The control sera were from 25 men and 38 women with ages ranging from 23 to 79 years (mean $34 \cdot 2$ ). They were members of the medical staff or residents of a home for the elderly. All the serum samples were stored at $-70^{\circ} \mathrm{C}$ until tested.

\section{CELL LINE}

IMR-33, derived from a gerbil fibroma, was originally obtained from the American Type Culture Collection (Rockville, MD), and cultured in minimal essential medium 199 supplemented with $20 \%$ heat inactivated fetal calf serum and antibiotics. Cells were seeded onto multispot slides after brief trypsinisation of stock cultures. Some of them were treated with colchicine $(20 \mu \mathrm{g} / \mathrm{ml})$ for 18 hours before use. After washing the slides with phosphate buffered saline (PBS), pH 7.4, the cells were fixed in methanol at $-20^{\circ} \mathrm{C}$ for 10 minutes, rinsed for 15 seconds in acetone prechilled to $-20^{\circ} \mathrm{C}$, and thoroughly washed in PBS before serum samples were applied.

IN DIRECT IMMUNOFLUORESCENCE

The slides were incubated for 45 minutes at $20^{\circ} \mathrm{C}$ in a moisture chamber with the sera diluted 1:10 in PBS containing $0 \cdot 1 \% \mathrm{NaN}_{3}$ to prevent contamination, washed three times with PBS, and further incubated for 45 minutes at $20^{\circ} \mathrm{C}$ with a second layer of two antibodies mixed 50:50 together. These were an affinity purified, fluorescein conjugated goat $\mathrm{F}\left(\mathrm{ab}^{\prime}\right)_{2}$ antihuman $\operatorname{IgM}, \mu$ chain specific, and an affinity purified, Texas red conjugated goat $\mathrm{F}\left(\mathrm{ab}^{\prime}\right)_{2}$ antihuman IgG, $\gamma$ chain specific (Jackson Immunoresearch Laboratories, Avondale, PA). After extensive washing with PBS the final preparation was covered with a glycerol mounting solution containing $25 \mathrm{~g} / 1$ diazobicyclo-octane to prevent fading. ${ }^{15}$ Cells were examined under a Leitz Dialux 22 fluorescence microscope equipped with epifluorescence illumination and the appropriate filters for fluorescein and Texas red. Pictures were taken on Fujichrome film with an oil immersion objective Leitz Neofluar $(50 \times)$. Cytoskeletal structures were identified by using a panel of commercially available (Boehringer, Mannheim, West Germany) monoclonal antibodies as markers. Positive sera stained cytoplasmic arrays of filaments in untreated cells (Fig. 1a) and perinuclear filamentous coils in colchi- cine treated cells (Fig. 1b). A titre of at least $1 / 10$ was considered positive.

ISOLATION AND PURIFICATION OF VI M E N T I

Vimentin intermediate sized filaments were isolated from human skin fibroblasts and purified by the method of Steinert et al. ${ }^{14}$ Briefly, the cells were lysed with PBS containing $0.6 \mathrm{M} \mathrm{KCl}, 1 \%$ Triton $\mathrm{X}-100,10 \mathrm{mM} \mathrm{MgC1} 2,0.5 \mathrm{mM}$ phenylmethylsulphonyl fluoride, $1 \mathrm{mg} / \mathrm{ml} N$-p-tosyl-L-arginine methyl ester $\mathrm{HCl}$ (TAME), and $0.5 \mathrm{mg} / \mathrm{ml}$ DNAse 1 (Sigma Chemical Co, St Louis, MO). The pelleted filaments were resuspended $(1 \mathrm{mg} / \mathrm{ml}$ total protein $)$ in $5 \mathrm{mM}$ trometamol (TRIS) $\mathrm{HCl}, 1 \mathrm{mM}$ dithiothreitol, $1 \mathrm{mM}$ ethyleneglycol-bis $\left(N, N^{\prime}\right.$-tetra-acetic acid), and 1 $\mathrm{mg} / \mathrm{ml}$ TAME, homogenised and dialysed against 1000 volumes of PBS for 16 hours at $4^{\circ} \mathrm{C}$. Centrifugations at $40000 \mathrm{~g}$ for 15 minutes and $250000 \mathrm{~g}$ for one hour were performed to clarify the solution. Vimentin reassembled within six hours at $4^{\circ} \mathrm{C}$ upon addition of $2.5 \mathrm{M} \mathrm{KCl}$ to a final concentration of $0 \cdot 17 \mathrm{~mol} / \mathrm{l}$. It was then purified by two further cycles of disassembly-reassembly.

ENZYME LINKED IMMUNOSORBENT ASSAY An ELISA ${ }^{15}$ was performed by a modification of the microtitre technique of Voller et al, ${ }^{16}$ which will be described in detail elsewhere (Boehme and Blaschek, manuscript in preparation). Aliquots of vimentin intermediate sized filaments were put into polyvinylchloride microtitre plates $(10 \mu \mathrm{g} / \mathrm{ml}, 300$ $\mu \mathrm{l} /$ well), and the plates were incubated at $37^{\circ} \mathrm{C}$ for three hours. After three washes with PBS containing $0.05 \%$ Tween 20 (PBS-Tween) the plates were incubated with PBS containing $0 \cdot 3 \%$ gelatin for five minutes to allow blocking of any free binding sites. Test sera, diluted 1:500 in PBS-Tween, were then incubated in triplicate wells for three hours at room temperature. After washing the wells three times with PBS-Tween a mixture 50:50 of peroxidase conjugated, rabbit antihuman IgM (Medac, Hamburg, West Germany) and alkaline phosphataseconjugated, goat antihuman IgG (Dako, Glostrup, Denmark), both 1:500 in the same diluent as used for the sera, was added, then after a three hour incubation the plates were washed three times in PBS-Tween. $o$-Phenylenediamine and $p$-nitrophenyl phosphate were used as substrates for anti-IgM and anti-IgG antibodies respectively. The absorbance at 492 and at $405 \mathrm{~nm}$ was read in a Titertek multiscanner (Flow Laboratories, McLean, VA). Standard curves were prepared with a reference serum, previously tested on several cell line preparations for AVA by indirect immunofluorescence assay and found to be strongly positive. 


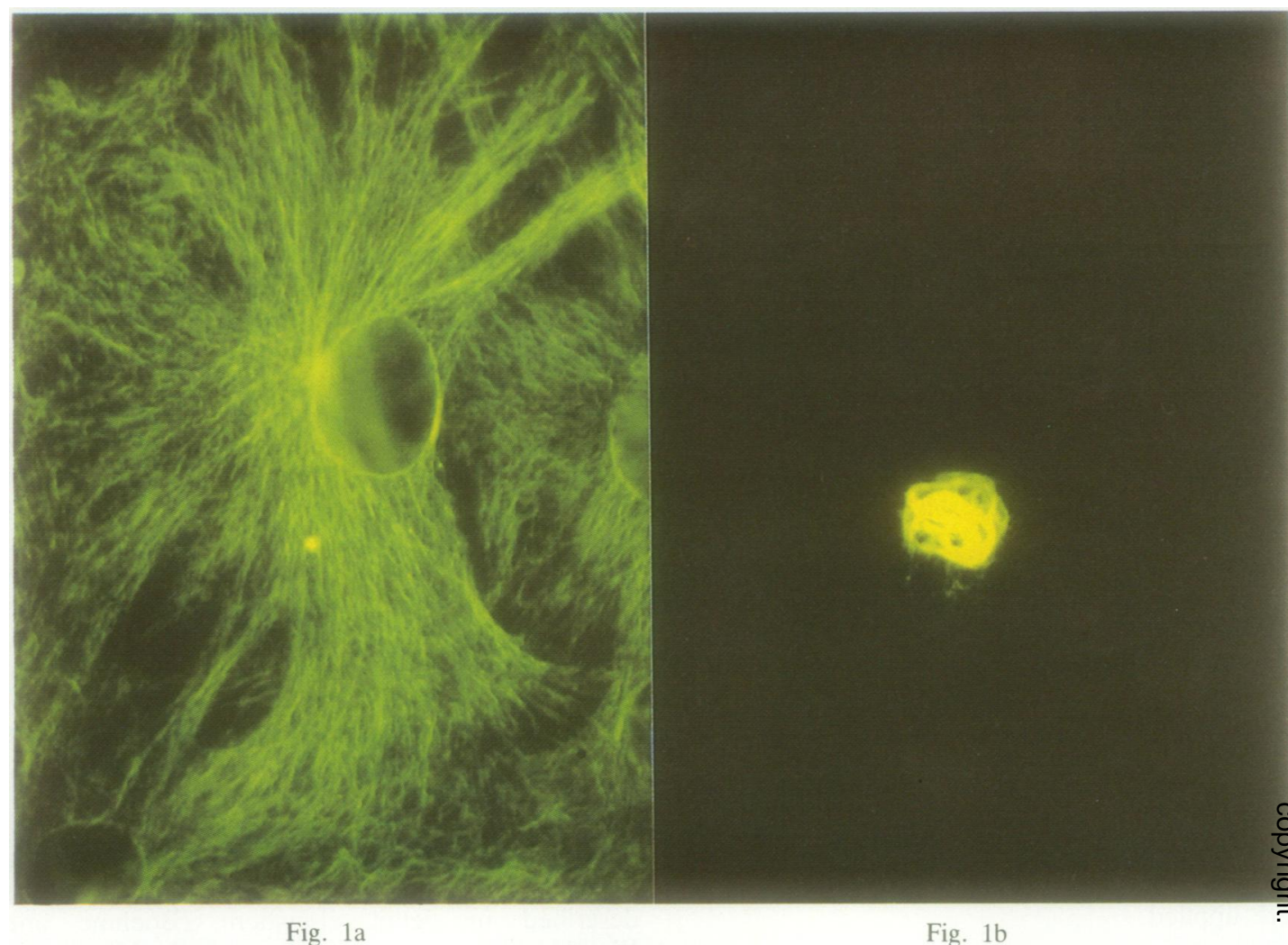

Fig. 1 Identification of IgM-antivimentin antibody $(A V A)$ by indirect immunofluorescence. (a) Fluorescence pattern due to a systemic lupus erythematosus serum on IMR-33 cell line. (b) The coiling of AVA around the nucleus after treatment with colchicine.

AVA INHIBITION BY CARDIOLIPIN

Ethanol was evaporated from the cardiolipin stock solution (Sigma Chemical Co) under a nitrogen stream, and the dried phospholipid was then dissolved in PBS-Tween to a concentration of 800 $\mu \mathrm{g} / \mathrm{ml}$ under sonication. Three AVA positive and ACA positive sera from patients with SLE and three AVA-negative/ACA-positive sera from patients with syphilis were diluted 1:250 in PBS-Tween. Aliquots were incubated in a $1: 1$ ratio with varying amounts of the cardiolipin inhibitor $(100,200,400$, and $800 \mu \mathrm{g}$ ) for one hour at $20^{\circ} \mathrm{C}$ and one hour at $4^{\circ} \mathrm{C}$. Sera were then centrifuged at $3000 \mathrm{~g}$ for 15 minutes at $22^{\circ} \mathrm{C}$, and supernatants were tested for AVA by ELISA according to the method outlined above.

\section{AVA ABSORPTION WITH SINGLE}

STRANDED DNA

Salmon sperm DNA (Sigma Chemical Co) was denatured by heating at $90^{\circ} \mathrm{C}$ for 10 mintues and fast cooling to $0^{\circ} \mathrm{C}$, and ssDNA was fixed to cyanogen bromide (CNBr) activated Sepharose 4B (Pharma cia, Upsala, Sweden) by means of poly-L-lysine aq $20^{\circ} \mathrm{C}$ by the method of Kubota et al. ${ }^{17}$

Sepharose human Cohn fraction II (CFII) an Sepharose bovine serum albumin (BSA) were pre3 pared by coupling CFII and BSA (Sigma Chemicad Co) respectively, to a concentration of $5 \mathrm{mg}$ protein/ml Sepharose. Serum samples from five patients with SLE were diluted 1:2, passed throug the ssDNA, CFII, or BSA column and reconcen trated until the original sample volume wasobtained. The effluents were diluted 1:500 an tested for AVA.

OTHER SEROLOGICAL TESTS ACA were determined by the ELISA technique described by Harris et al. ${ }^{18}$ Alkaline phosphatas conjugated, goat antihuman immunoglobulins (IgG IgM, and IgA; Sigma Chemical Co) diluted 1:500 were used. Fifty microlitres of $1 \mathrm{mg} / \mathrm{ml} p_{\overrightarrow{0}}$ nitrophenyl phosphate in diethanolamine buffer, $\mathrm{pH}$ 9.8, was added to each well. After 45 minutes the्ष 
reaction was stopped by adding $50 \mu$ laliquots of $3 \mathrm{M}$ sodium hydroxide to each well. Absorbance was read at $405 \mathrm{~nm}$. Standard positive sera were supplied by Dr E N Harris, St Thomas's Hospital, London.

Anti-dsDNA antibodies were tested by a commercial ELISA kit purchased from Cordis Laboratories (Miami, Flor) and the results reported in international units/ml (IU) traceable to the World Health Organisation antinuclear antibody serum.

To set up the ELISA test for anti-ssDNA antibodies, dsDNA (Sigma Chemical Co) was denatured as previously described, coated to discs (Cordis Laboratories Inc), and processed as above. ${ }^{19}$

\section{STATISTICAL ANALYSIS}

All tests were performed in triplicate and the data were averaged. In the five ELISA tests the upper limit of normality was taken as two standard deviations above mean normal control levels. The sensitivity and the specificity of the tests for SLE were calculated using the formulas established by Youden. ${ }^{20}$ Specificity is the number of subjects without presumed SLE with a negative assay divided by the number of subjects without presumed SLE, i.e., the true negative rate. Sensitivity is the number of patients with SLE with a positive assay divided by the number of patients with SLE, i.e., the true positive rate.

The analysis of these data was carried out using the Statistical Package for the Biological Sciences on the Person 1600 IBM compatible at the French National Institute of Marine Biology computing centre. The relation between autoantibodies and certain clinical features was examined using $\chi^{2}$ analysis with Yates's correction for small numbers. Correlations between the different autoantibodies were established by Spearman's correlation coefficient. A stepwise principal component analysis was performed. This method of analysis allows the evaluation of the statistical weight of each of the five quantitative variables (ACA, IgM-AVA, IgGAVA, anti-dsDNA, and anti-ssDNA antibodies) in a system of five orthogonal axes (one for each of the variables). The percentage of the total variance (the total variance is the variance of the five variables multiplied by the number of individuals, i.e., 50) is accounted for by each of the axes.

\section{Results}

Analysis of the 50 serum samples from patients with SLE and 63 from normal controls by indirect immunofluorescence assay (Table 1) showed that 19 $(38 \%)$ and $11(17 \%)$, respectively, had significantly raised titres of IgM-AVA whereas eight $(16 \%)$ and four $(6 \%)$, respectively, had significantly raised titres of IgG-AVA. With the ELISA (Fig. 2), of the
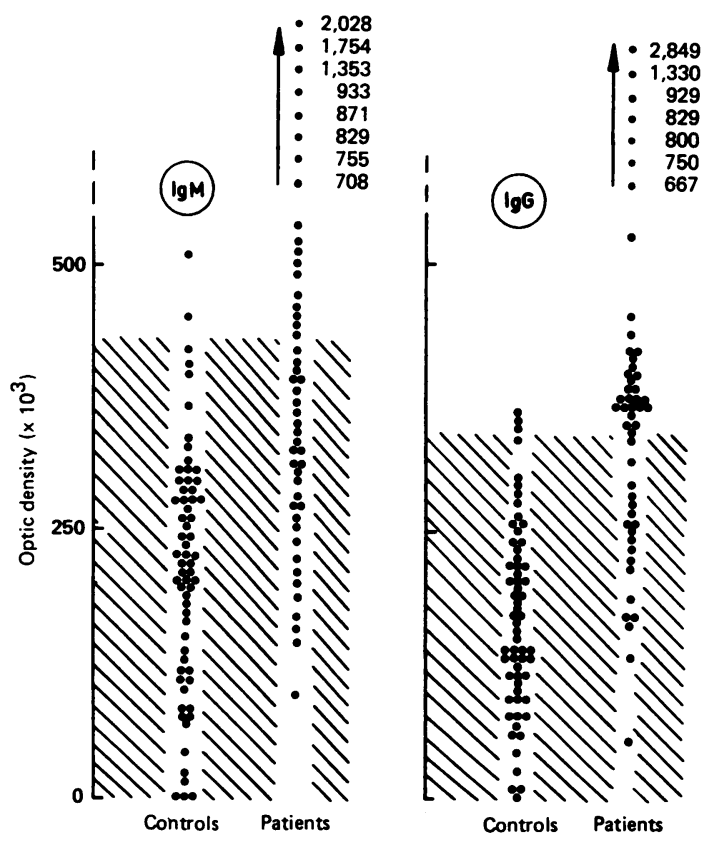

Fig. 2 Optical densities obtained with antivimentin antibody by an enzyme linked immunosorbent assay in serum samples from 50 patients with systemic lupus erythematosus and from 63 normal controls.

Table 1 Prevalence of IgM- and IgG-antivimentin antibodies by indirect immunofluorescence and enzyme linked immunosorbent assay in serum samples from 50 patients with systemic lupus erythematosus and from 63 normal controls

\begin{tabular}{|c|c|c|c|c|c|}
\hline \multirow[t]{2}{*}{$I I F^{*}$} & \multirow[t]{2}{*}{$E L I S A^{*}$} & \multicolumn{2}{|c|}{$\lg M-A V A^{*}$} & \multicolumn{2}{|c|}{$\lg G-A V A$} \\
\hline & & $\begin{array}{l}\text { No of } \\
\text { patients }\end{array}$ & $\begin{array}{l}\text { No of } \\
\text { controls }\end{array}$ & $\begin{array}{l}\text { No of } \\
\text { patients }\end{array}$ & $\begin{array}{l}\text { No of } \\
\text { controls }\end{array}$ \\
\hline+ & + & 13 & 1 & 6 & 0 \\
\hline+ & - & 6 & 10 & 2 & 4 \\
\hline- & + & 5 & 1 & 26 & 3 \\
\hline- & - & 26 & 51 & 16 & 56 \\
\hline
\end{tabular}

${ }^{*} I I F=$ indirect immunofluorescence: $E L I S A=$ enzyme linked immunosorbent assay: AVA=antivimentin antibody. 
63 serum samples from normal controls, the range of absorbance at $492 \mathrm{~nm}$, representing the results for IgM-AVA, was $0 \cdot 010-0.507$ (mean (SD) $0 \cdot 214$ $(0 \cdot 113))$, and the upper limit of normal was set at 0.440 optical density (OD) units (mean $+2 S D$ ). The range of absorbance at $405 \mathrm{~nm}$, representing the results for IgG-AVA, was $0 \cdot 009-() \cdot 375$ (mean (SD) $0 \cdot 172(0 \cdot 087))$, and the upper limit of normal was set at 0.346 OD units (mean $+2 \mathrm{SD})$. Eighteen $(36 \%)$ of the 50 SLE sera contained raised levels of IgMAVA and $32(64 \%)$ raised levels of IgG-AVA.

Comparison of the indirect immunofluorescence assay and ELISA methods of measuring AVA (Table 1) showed that the latter was more specific and more sensitive than the former technique (specificity: $97 \% v 83 \%$ for IgM-AVA, and 95\%v 94\% for IgG-AVA; sensitivity: $38 \% \vee 38 \%$ for IgMAVA, and $52 \% \vee 16 \%$ for IgG-AVA). Therefore, for convenience, only the ELISA results will be referred to in the following part.

Table 2 shows the number of serum samples from patients and controls in which increased activity against vimentin, cardiolipin, dsDNA, and ssDNA was detected.

Table 2 Results of various serological investigations in 50 patients with systemic lupus erythematous and in 63 normal controls

\begin{tabular}{lll}
\hline & $\begin{array}{l}\text { No }(\%) \text { positive } \\
\text { Patients }(n=50)\end{array}$ & Controls $(n=63)$ \\
\hline AVA $^{*}$ & $33(66)$ & $+(6)$ \\
ACA & $27(54)$ & $1(2)$ \\
Anti-dsDNA Ab* & $44(88)$ & $2(3)$ \\
Anti-ssDNA Ab* & $43(86)$ & $3(5)$ \\
\hline
\end{tabular}

*AVA=antivimentin antibody; $\mathrm{ACA}=$ anticardiolipin antibody; anti-dsDNA $A b=$ anti-double-stranded DNA antibody; anti-ssDNA $\mathrm{Ab}=$ anti-single-stranded DNA antibody.

Table 3 Correlation of antivimentin, anticardiolipin, and anti-DNA antibodies

\begin{tabular}{lllll}
\hline & $A C A$ & $\lg M-A V A$ & $\operatorname{Ig} G-A V A$ & dsDNA \\
\hline IgM-AVA & $\mathrm{r}=0.52$ & - & - & - \\
IgG-AVA & $\mathrm{p}<0.001$ & & & - \\
& $\mathrm{r}=0.09$ & $\mathrm{r}=0.29$ & - & - \\
dsDNA & $\mathrm{p}>0.10$ & $\mathrm{p}<0.05$ & & \\
& $\mathrm{r}=0.42$ & $\mathrm{r}=0.27$ & $\mathrm{r}=0.11$ & - \\
ssDNA & $\mathrm{p}<0.01$ & $\mathrm{p}>0.05$ & $\mathrm{p}>0.10$ & \\
& $\mathrm{r}=0.77$ & $\mathrm{r}=0.46$ & $\mathrm{r}=0.12$ & $\mathrm{r}=0.25$ \\
& $\mathrm{p}<0.001$ & $\mathrm{p}<0.001$ & $\mathrm{p}>0.10$ & $\mathrm{p}>0.05$ \\
\hline
\end{tabular}

Correlations established using Spearman's correlation coefficient. For abbreviations see Tables 1 and 2 .
Correlations were sought between IgM-AVA IgG-AVA, ACA, anti-dsDNA antibodies, and antissDNA antibodies (Table 3 ). Statistically significant correlations were found between both isotypes of $\stackrel{9}{9}$ AVA, between IgM-AVA and ACA/anti-ssDNA antibodies, and between ACA and both anti-DNA antibodies. Because this study was devoted to AVA

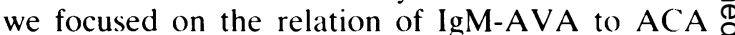
$(\mathrm{r}=0.52)$ and to anti-ssDNA antibodies $(\mathrm{r}=(0.46)$. Twenty ACA positive sera from patients with

Table 4 Results of the stepwise principal component analysis

\begin{tabular}{lll}
\hline Axis & Variables associated & $\begin{array}{l}\% \text { Of the total variance } \\
\text { accounted for by } \\
\text { each of the axes }\end{array}$ \\
\hline 1 & IgM-AVA & 48.551 \\
2 & IgG-AVA & 22.583 \\
3 & ACA & 14.449 \\
4 & anti-dsDNA Ab & 7.854 \\
5 & anti-ssDNA Ab & 6.563
\end{tabular}

*Total variance $=50$ patients $\times 5$ variables.

For abbreviations see Tables 1 and 2 .

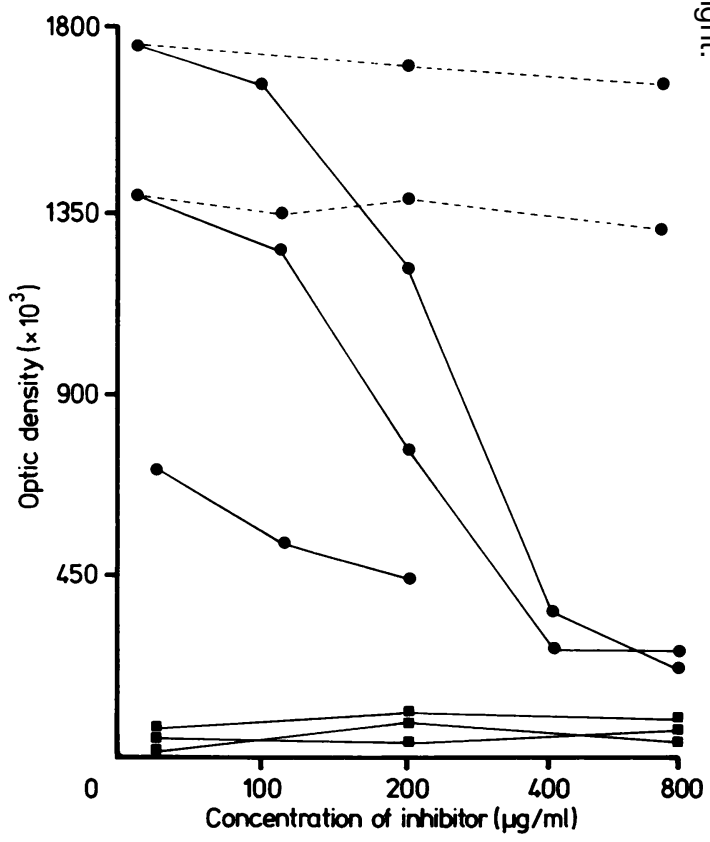

Fig. 3 Inhibition of IgM-antivimentin antibody by cardiolipin $(C L)$. Systemic lupus erythematosus serum inhibited by $C L=\longrightarrow$, or by bovine serum albumin $(B S A)=-$ - Syphilis serum inhibited by $C L$ or $B S A=$ 


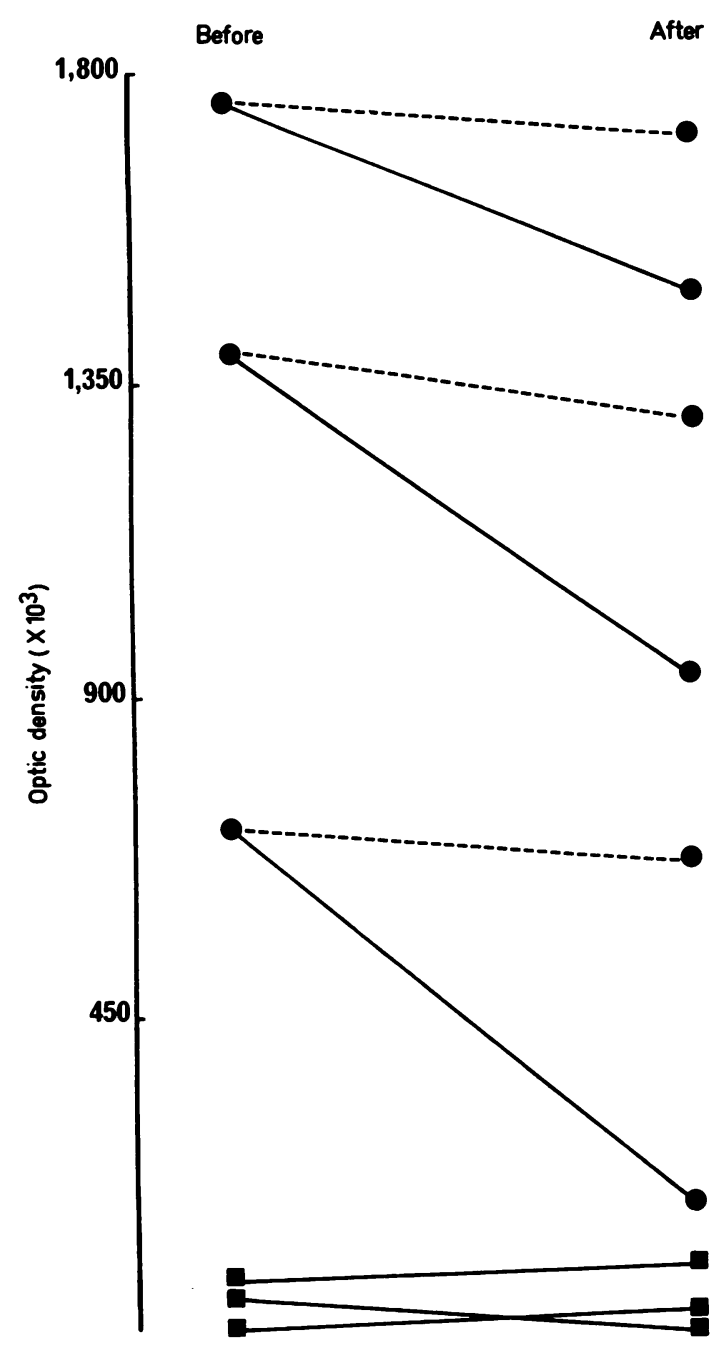

Fig. 4 Absorption of IgM-antivimentin antibody with single stranded DNA (ssDNA). Systemic lupus erythematosus serum absorbed with ss $D N A=0$, or by bovine serum albumin $(B S A)=0-1$. Syphilis serum absorbed with ssDNA or BSA = $\square$. syphilis were examined for the presence of IgMAVA and IgG-AVA. Three $(15 \%)$ and two $(10 \%)$, respectively, were found to be positive.

Inhibition experiments with cardiolipin liposomes were carried out for three SLE and three syphilis sera (Fig. 3), and the same sera were extensively absorbed with ssDNA (Fig. 4). The binding was readily inhibited by cardiolipin liposomes, and to a lesser degree absorbed with ssDNA, whereas BSA and human CFII were inefficient.

Table 4 and Fig. 5 show the results of the stepwise principal component analysis. It can be seen that axis 1 (IgM-AVA) accounts for $48.6 \%$ and axis 2 (IgG-AVA) for $22.6 \%$ of the total variance (total variance $=$ the variance of five variables multiplied by 50 patients). Thus axes 1 and 2 appear to be the most important axes as together they account for $71.2 \%$ of the total variance. This is correct when considering the patients group as a whole, but is incorrect when considering any given individual.

Careful review of the charts of these 50 patients with SLE (Table 5) showed that IgG-AVA were significantly associated with arthralgia in SLE.

\section{Discussion}

In the present study serum samples from patients with SLE were shown to react with cytoskeletal proteins. There is a six year difference in the average age of the patients with SLE and the normal controls, and the range is much wider in the former than in the latter group. There are no data on the variability of these autoantibodies with age, however. Despite the close association in cells between vimentin and tubulin we can exclude the latter protein. Indeed, the pattern of indirect immunofluorescence assay obtained in cells treated with colchicine, an inhibitor of microtubule polymerisation, indicates that the fibrous pattern is due to vimentin, ${ }^{21}$ and the molecular weight of the protein used to coat the wells in the ELISA test (Boehme and Blaschek, manuscript in preparation) has been

Table 5 Clinical features associated with IgM and IgG antivimentin antibodies (AVA). The number of patients suffering from a given clinical symptom is in parentheses on the left. Of these, some have IgM-AVA or IgG-AVA, or both

\begin{tabular}{|c|c|c|c|c|c|c|c|c|}
\hline \multirow{2}{*}{$\begin{array}{l}\text { Clinical } \\
\text { features }\end{array}$} & \multicolumn{4}{|c|}{$\operatorname{Ig} M-A V A$} & \multicolumn{4}{|c|}{$\operatorname{Ig} G-A V A$} \\
\hline & Positive & Negative & $x^{2+}$ & $p$ Value & Positive & Negative & $x^{2}$ & p Value \\
\hline Arthralgia $(n=40)$ & 16 & 24 & $0 \cdot 66$ & 0.42 & 30 & 10 & $8 \cdot 25$ & $0 \cdot 01$ \\
\hline Renal discase $(n=22)$ & 6 & 16 & 1.41 & $0 \cdot 24$ & 15 & 7 & 0.35 & 0.55 \\
\hline CNS $^{*}$ disease $(n=9)$ & 5 & 4 & 0.93 & $0 \cdot 34$ & 7 & 2 & 0.32 & 0.57 \\
\hline Rash $(n=44)$ & 17 & 27 & 0.66 & 0.42 & 30 & 14 & $1 \cdot 38$ & $0 \cdot 24$ \\
\hline
\end{tabular}

${ }^{*} \mathrm{CNS}=$ central nervous system.

$+\chi^{2}$ with Yates's correction for small numbers. 


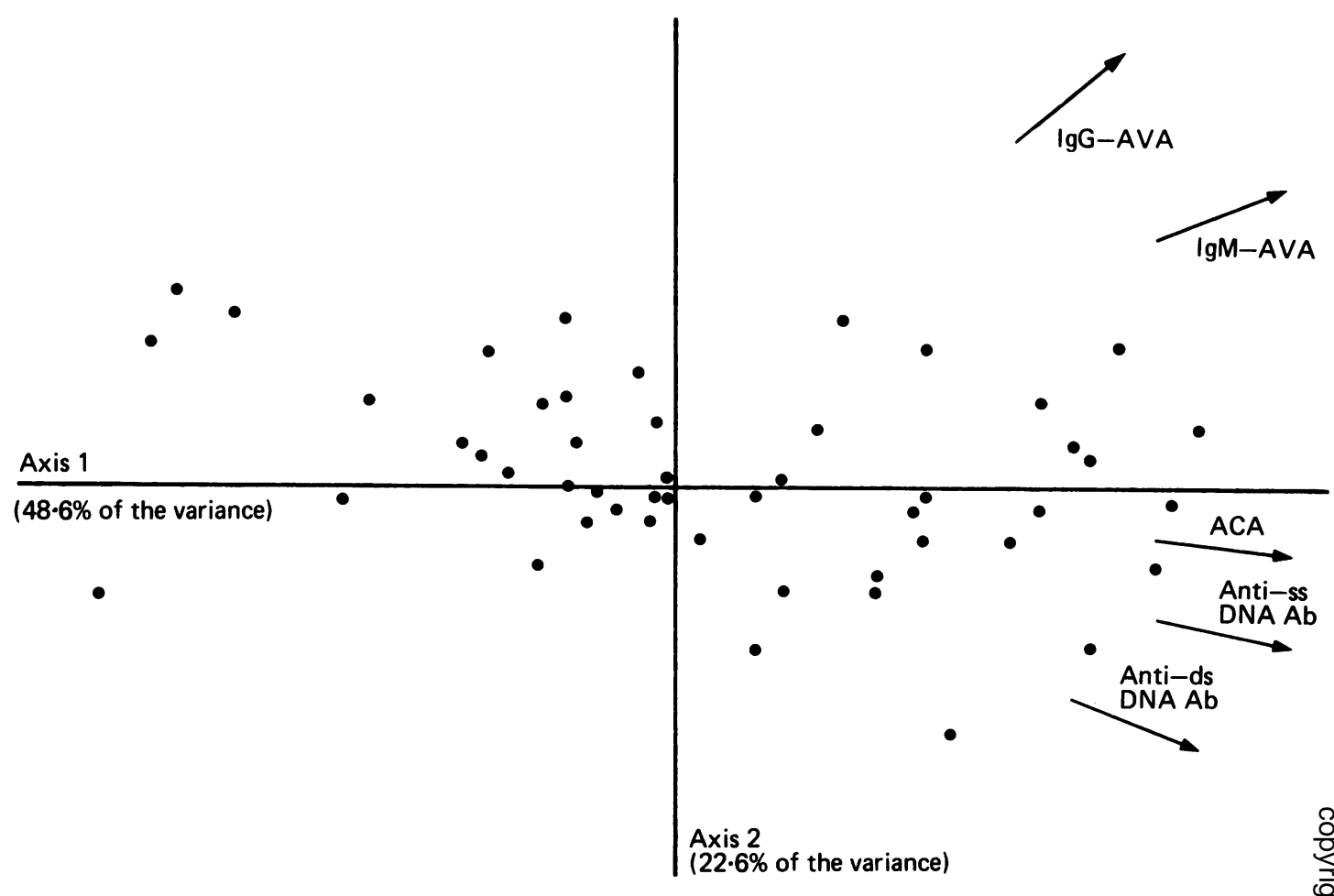

Fig. 5 Stepwise principal component analysis. Distribution of 50 patients with systemic lupus erythematosus according to: axis 1 (IgM-AVA) and axis $2(\lg G-A V A)$. This combination of axes accounts for $48 \cdot 6+22 \cdot 6=71 \cdot 2 \%$ of the total variance (see text).

shown to be 54000 by sodium dodecyl sulphatepolyacrylamide gel electrophoresis. ${ }^{22}$ Detection of AVA with class specific antisera to human IgG or IgM suggests that AVA are composed of both classes of immunoglobulins in the sera from patients with SLE. An effect of detergent in PBS-Tween on the cardiolipin liposome is possible, but as a difference was shown between SLE and syphilis, this is probably not significant.

Osung $e$ et al found that the prevalence of AVA was $10 \%$ in sera from patients with SLE, ${ }^{23}$ whereas Alcover et al, ${ }^{5}$ Kurki et $a l^{6}{ }^{6}$ and Senecal et $a l^{7}$ reported that $38-53 \%$ of SLE sera contained AVA. Our immunofluorescence results agree with these findings. In an attempt to resolve the discrepancies between reports we performed further experiments with an ELISA, a technique claimed to be more sensitive than indirect immunfluorescence assay. The prevalence of IgM-AVA was $36 \%$, and that of IgG-AVA $64 \%$, in SLE sera.

Statistical analysis of the serological results from 50 patients with SLE showed correlations between AVA and other non-organ-specific autoantibodies.
We showed a significant association between AVA, ACA, and anti-DNA antibodies, especially between IgM-AVA, on the one hand, and ACA and anti-? ssDNA antibodies, on the other. Further, the stepwise principal component analysis showed that IgM-AVA and IgG-AVA accounted for $71 \%$ of the total variance (variance of 50 patients $\times 5$ parameters). Although the statistical correlations do not $\stackrel{3}{3}$ prove that a given antibody may necessarily bind to two different antigens, they make it more likely. Prompted by this observation, we sought AVA in 20 ACA positive sera from patients with syphilis, but none of them reacted with cytoskeletal proteins. $\sigma$ IgM-AVA from patients with SLE were inhibited by cardiolipin and absorbed with ssDNA.

These results are not surprising, given the pre- $\omega$ viously described cross reactions, ${ }^{24}{ }^{26}$ Murine ${ }^{27}$ and 2 human $^{28}$ monoclonal anti-DNA antibodies can bind $\stackrel{\circ}{\subset}$ to cardiolipin, and human monoclonal anti-DNA antibodies from patients with SLE $^{29}$ and from:normals $^{30}$ can bind to cytoskeleton proteins. Any relation between ACA and AVA has never been $\overrightarrow{\widetilde{D}}$ unequivocally shown. Several indirect arguments $\frac{\rho}{\mathbb{Q}}$ 
may be put forward. For example, patients with Behçet's disease have been shown to be capable of making antibodies to cardiolipin ${ }^{31}$ and antibodies to the cytoskeleton. ${ }^{32} \mathrm{ACA}^{31}$ and $\mathrm{AVA}^{5-723}$ exist in normal sera. We showed hardly any AVA positive serum in syphilis despite the presence of ACA in this disease. This may be due to differences in epitope specificity. ACA from patients with SLE are more likely to bind to phosphatidylserine than to phosphatidylethanolamine, and vice versa with syphilis serum. ${ }^{33}$ The binding of syphilitic antibodies to cardiolipin was readily inhibited by cardiolipin liposomes, whereas this pattern of reactivity was noted in only one of four sera from patients with acute infection by Vaarala et al. ${ }^{34}$

The successful inhibition of AVA from SLE with cardiolipin may mean that the epitope shared by vimentin and phospholipids is related to phosphatidylserine. ${ }^{27}$ Some of the ACA, however, may react with the cytoskeletal epitopes that are shared with vimentin. 35

Analysis of the clinical details showed an association between AVA positivity and arthralgia. One explanation of this finding is that proliferating synovial lining cells contain vimentin as a prominent constituent. ${ }^{36}$ Thus a vicious circle may be set off once joints are involved.

The cross reaction between vimentin, cardiolipin, and DNA raises the important question of polyreactive autoantibodies. The likelihood that DNA is the immunogen in SLE is extremely questionable. $^{24-26} 37$

We are indebted to Professor E J Holborow (London, UK) and to Dr M J Fritzler (Calgary, Canada) whose advice enabled us to set up this study. The technical expertise of Miss Nelly Jezequel and Mrs Simone Forest has been greatly appreciated. We are most grateful to Specia Pharmaceutical Company (Paris) for financial support. This study was supported by a grant from Le Ministère de la Recherche et de la Technologie, and by a grant from Le Comité Départemental de la Ligue Nationale contre le Cancer. MAB was supported by a doctoral fellowship from the Studienstiftung des deutschen Volkes.

\section{References}

1 Lazarides E. Intermediate filaments as mechanical integrators of cellular space. Nature 1980; 283: 249-56.

2 Bretherton L, Toh B H, Jack I. IgM autoantibody to intermediate filaments in Mycoplasma pneumoniae infections. Clin Immunol Immunopathol 1981; 18: 425-30.

3 Boehme M W J, Evans D A, Miles M A, Holborow E J. Occurrence of autoantibodies to intermediate filament proteins in human visceral leishmaniasis and their induction by experimental polyclonal B-cell activation. Immunology 1986; 59: 583-8.

4 Kataaha P K, Mortazavi-Milani S M, Russell G, Holborow E J. Anti-intermediate filament antibodies, antikeratin antibody, and antiperinuclear factor in rheumatoid arthritis and infectious mononucleosis. Ann Rheum Dis 1985; 44: 446-9.

5 Alcover A, Molano J, Renart J, Gil-Aguado A, Nieto A,
Avila J. Antibodies to vimentin intermediate filaments in sera from patients with systemic lupus erythematosus. Arthritis Rheum 1984; 27: 922-8.

6 Kurki P, Helve T, Virtanen I. Antibodies to cytoplasmic intermediate filaments in rheumatic diseases. $J$ Rheumatol 1983; 10: 558-62.

7 Senecal J L, Oliver J M, Rothfield N. Anticytoskeletal autoantibodies in the connective tissue diseases. Arthritis Rheum 1985; 28: 889-98.

8 Blaschek M A. Nicht-organspezifische antizytoplasmatische Autoantikörper. Immunoserologischer Nachweis und diagnostische Relevanz. Wien Med Wochenschr 1987; 13: 303-9.

9 Youinou P. Le Goff P, Miossec P, Moineau M P, Ferec C. Untersuchungen zur Beziehung zwischen anti-perinukleären Faktoren, Anti-Keratin-Antikörpern und dem agglutinierenden und nicht-agglutinierenden Rheumafaktor bei der chronischen Polyarthritis. Z Rheumatol 1983; 42: 36-9.

10 Youinou P, Le Goff P. Colaco C B, et al. Antikeratin antibodies in serum and synovial fluid show specificity for rheumatoid arthritis in a study of connective tissue diseases. Ann Rheum Dis 1985; 44: 450-4.

11 Cohen A S. Reynolds W E, Franklin E C, et al. Preliminary criteria for the classification of systemic lupus erythematosus. Bull Rheum Dis 1971; 21: 643-8.

12 Tan E M, Cohen A S, Fries J F, et al. The 1982 revised criteria for the classification of systemic lupus erythematosus. Arthritis Rheum 1982; 25: 1271-7.

13 Johnson G D, Davidson R S, McNamee K C. Russell G. Goodwin D, Holborow E J. Fading of immunofluorescence during microscopy: a study of the phenomenon and its remedy. J Immunol Methods 1982; 55: 231-42.

14 Steinert P, Zackroff R, Aynardi-Whitman M, Goldman R D. Isolation and characterization of intermediate filaments. Methods Cell Biol 1982; 24: 399-418.

15 Engvall E, Perlmann P. Enzyme-linked immunosorbent assay, ELISA. III. Quantitation of specific antibodies by enzymelabelled anti-immunoglobulin in antigen-coated tubes. J Immunol 1972; 109: 129-35.

16 Voller A, Bidwell D, Huldt G, Engvall E. A microplate method of enzyme-linked immunosorbent assay and its application to malaria. Bull WHO 1974; 51: 209-11.

17 Kubota T, Akatsuka T, Kanai Y. DNA affinity column chromatography: application in the isolation of distinct antibody populations from SLE sera. Clin Exp Immunol 1985; 62: $321-8$.

18 Harris E N, Gharavi A D, Patel S P, Hughes G R V. Evaluation of the anti-cardiolipin antibody test: report of an international workshop held 4 April 1986. Clin Exp Immunol 1987; 68: 215-22.

19 Klotz J L, Minami R M, Teplitz R L. An enzyme-linked immunosorbent assay for antibodies to native and denatured DNA. J Immunol Methods 1979; 29: 155-65

20 Youden W J. Index for rating diagnostic test. Cancer 1950; 3: 32-5.

21 Osborn M, Franke W W, Weber K. Direct demonstration of the presence of two immunologically distinct intermediate-sized filament systems in the same cell by double immunofluorescence microscopy: vimentin and cytokeratin fibers in cultured epithelial cells. Exp Cell Res 1980; 125: 37-46.

22 Lazarides E. Intermediate filaments. A chemically heterogeneous developmentally regulated class of proteins. Ann Rev Biochem 1982; 51: 219-50.

23 Osung D A, Chandra M, Holborow E J. Antibody to intermediate filaments of the cytoskeleton in rheumatoid arthritis. Ann Rheum Dis 1982; 41: 69-73.

24 Eilat D. Anti-DNA antibodies: problems in their study and interpretation. Clin Exp Immunol 1986; 65: 215-22.

25 Emlen W, Pisetoky D S, Taylor R P. Antibodies to DNA, a perspective. Arthritis Rheum 1986; 29: 1417-26. 
26 Isenberg D, Shoenfeld $\mathrm{Y}$. The origin and significance of antiDNA antibodies. Immunol Today 1987: 8: 279-82.

27 Lafer M, Rauch J, Andrzejewski C Jr, et al. Polyspecific monoclonal lupus autoantibodies reactive with both polynucleotides and phospholipids. J Exp Med 1981; 153: 897-909.

28 Shoenfeld Y, Rauch J, Massicotte H. et al. Polyspecificity of monoclonal lupus autoantibodics produced by human-human hybridomas. $N$ Engl J Med 1983: 308: 414-20.

29 André-Schwartz J, Katta S K. Shoenfeld Y. Isenberg D A. Stollar B D. Schwartz R S. Binding of cytoskeletal proteins by monoclonal anti-DNA lupus autoantibodies. Clin Immunol Immunopathol 1984: 31: 261-71.

30 Cavins E. Komar R. Bell D A. Cytoskeletal binding of monoclonal anti-DNA antibodies derived from tonsillar lymphoid cells of a normal subject. Arthritis Rheum 1986; 29: 1351-8.

31 Hull R G, Harris E N, Gharavi A E, et al. Anticardiolipin antibodies: occurrence in Behçet's syndrome. Ann Rheum Dis 1984: 43: $746-8$.
32 Akoglu T. Kozakoglu H. Akoglu E. Antibody to intermediate filaments of the cytoskeleton in patients with Behçet's disease Clin Immunol Immunopathol 1986; 41: 427-32.

33 Colaco C B. Male D K. Anti-phospholipid antibodies in syphilis and a thrombotic subset of SLE: distinct profiles of epitope? specificity. Clin Exp Immunol 1985; 59: 449-56.

34 Vaarala O. Palosuo T, Klecmole M. Aho K. Anticardiolipirõ responses in acute infections. Clin Immunol Immunopathotes 1986: 41: 8-15

35 Pruss R M. Mirsky R. Raff M C. All classes of intermediatc filaments share a common antigenic determinant defined by monoclonal antibody. Cell 1981: 27: 419-28.

36 Osung O A. Chandra M. Holborow E J. Intermediate filament $\vec{\circ}$ in synovial lining cells in rheumatoid arthritis and other arthritides are of vimentin type. Ann Rheum Dis 1982:41: 74-7 $\vec{\omega}$

37 Jacob L. Lety M A. Bach J F. Louvard D. Human systemie lupus erythematosus sera contain antibodies against cell-surface protein(s) that share(s) epitope(s) with DNA. Proc Natl Aca\& Sci USA 1986: 83: 6970-4. 